\title{
Some Physical and Mechanical Properties of Borate-Treated Oriental Beech Wood
}

\section{Određena fizikalna i mehanička svojstva orijentalne bukovine impregnirane boratima}

\author{
Original scientific paper • Izvorni znanstveni rad \\ Received-prispjelo: 22. 10. 2013. \\ Accepted-prihvaćeno: 20. 5. 2015. \\ UDK: $630 * 812 ; 630 * 84 ; 674.031 .632 .22$; \\ doi:10.5552/drind.2015.1356
}

\begin{abstract}
This study was designed to determine some physical properties such as surface roughness and oven dry density, and some mechanical properties such as modulus of elasticity (MOE) of borate-treated wood specimens. Wood specimens were prepared from Oriental beech (Fagus orientalis L.). Ammonium pentaborate octahydrate (APBO), ammonium tetrafluoroborate (ATFB), and sodium tetrafluoroborate (STFB) were used as borates. Before tests, wood specimens were impregnated with 0.25, 0.50, 1.50, and 3.00 percent aqueous solutions of borates.

The results showed that borate treatment caused increases in oven dry density and surface roughness, while it decreased MOE values of Oriental beech.
\end{abstract}

Keywords: borates, oven dry density, modulus of elasticity, surface roughness, Oriental beech

\begin{abstract}
SAŽETAK • Cilj istraživanja bio je odrediti neka fizikalna obilježja kao što su hrapavost površine i gustoća u apsolutno suhom stanju te određena mehanička svojstva kao što su modul elastičnosti (MOE) uzoraka drva impregniranih boratima. Uzorci drva izrađeni su od orijentalne bukovine (Fagus orientalis L.). Amonij pentaborat oktahidrat (APBO), amonij tetrafluoroborat (ATFB) i natrij tetrafluoroborat (STFB) upotrijebljeni su kao borati. Prije ispitivanja, uzorci drva impregnirani su otopinom vode i 0,25\%, 0,50\%, 1,50\% i 3,00\% borata.

Rezultati su pokazali da impregniranje drva orijentalne bukovine boratima pridonosi porastu gustoće u apsolutno suhom stanju i povećanju hrapavosti površine, a smanjuju se vrijednosti modula elastičnosti drva.
\end{abstract}

Ključne riječi: borati, gustoća u suhom stanju, modul elastičnosti, hrapavost površine, orijentalna bukovina

\footnotetext{
${ }^{1}$ Author is assistant at Gaziosmanpasa University, Vocational High School of Technical Sciences of Tokat, Department of Wood Science and Technology, Tokat, Turkey. ${ }^{2}$ Author is professor at Mugla Sitki Kocman University, Faculty of Technology, Department of Wood Science and Technology, Kotekli, Mugla, Turkey.

${ }^{1}$ Autor je asistent Sveučilišta Gaziosmanpasa, Stručna visoka škola tehničkih znanosti u Tokatu, Odjel za znanost o drvu i drvnu tehnologiju, Tokat, Turska. ${ }^{2}$ Autor je profesor Sveučilišta Mugla Sitki Kocman, Tehnološki fakultet, Odjel za znanost o drvu i drvnu tehnologiju, Kotekli, Mugla, Turska.
} 


\section{INTRODUCTION}

\section{UVOD}

Throughout the course of history, wood has remained one of the most important renewable natural resources available to man. It is a natural, cellular, composite material of botanical origin possessing unique structural and chemical characteristics that render it desirable for a broad variety of end users. (Yalinkilic, 2000). However, wood possesses several undesirable properties that impair its performance and limit its application. Flammability of wood is one of the most severe problems leading to huge loss of life and property (Lee et al., 2004). The flammability of wood can be reduced by treating wood with fire retardants. Most existing fire retardants are effective in reducing different fire parameters of wood such as ignitability, heat release, and flame spread. In recent years, there has been a rapid increase in the application of chemicals to wooden materials in order to improve their physical, mechanical, biological, and fire properties (Brelid et al., 2000; Chao and Lee, 2003; Su, 1997; Yalinkilic et al., 1999). Borates have several advantages as wood preservative in addition to imparting flame retardancy, providing sufficient protection against wood destroying organisms and low volatility. Moreover, they are colorless and odourless (Hafizoglu et al., 1994; Murphy, 1990; Drysdale, 1994; Chen et al., 1997). Threshold levels of boron against microorganisms and insects were extensively studied by many researchers (Drysdale, 1994; Grace et al., 1992; Tamashiro et al., 1991; Lloyd, 1993). Borates provide protection against all forms of wood destroying organisms, including decay fungi (such as wet and dry rot), wood boring beetles (such as common furniture beetle, house longhorn beetle, and powder post beetles) and termites (including dry wood and subterranean) (Lloyd et al., 1995). Baysal and Yalinkilic (2005) studied decay resistance of wood against brown and white rot fungi, impregnated with boron containing compound named PHN . They found that PHN imparted complete decay resistance against brown rot and white rot fungi Tyromycetes palustris and Coriolus versicolor, respectively. Simsek et al. (2010) investigated decay resistance of Oriental beech wood impregnated with some borates such as ammonium pentaborate octahydrate (APBO), ammonium tetrafluoroborate (ATFB), and sodium tetrafluoroborate (STFB). Results indicated that borate-treated wood showed considerable resistance against decay fungus compared to that of untreated control specimen. Kartal et al. (2004) reported that boron-containing quaternary ammonia compound, didecyl dimethyl ammonium tetrafluoroborate (DFB) treatment at $0.1 \%$ concentration was efficient against subterranean termites, Captotermes formosanus Shiraki bases on mass loss in both leached and unleached wood specimens. Also, it is well known that boron compounds work efficiently as fire retardant chemicals for cellulosic materials. The fire retardant properties of boron containing compounds were surveyed by many scientists and proven to be effective since late 19th centuries (Lyons, 1970). Yuksel et al. (2014) investi- gated combustion properties of Oriental beech impregnated with boric acid, borax, and sodium perborate. They found that mass loss and temperature values of borate-treated wood specimens were lower than untreated wood specimens at all combustion stages. Jin et al. (2014) studied fire resistance of disodium octoborate tetrahydrate, and boric acid impregnated Southern pine wood by TG analysis. They found that while the mass loss rate decreased, the char yield increased impregnated with borates after TG analysis. However, borates are generally leachable from treated wood in ground contact conditions (Yalinkilic et al., 1995). Therefore, the utilization of boron compounds is restricted to indoor conditions. Many attempts have already been made to reduce leaching of borates from treated wood through chemical fixation of boron. Baysal et al. (2004) investigated leaching of boric acid from Sugi wood when boric acid mixed with furfuryl alcohol. Results of the leaching tests indicated that boric acid readily lost its boron content in the early cycles of the leaching periods. When furfuryl alcohol was mixed with borates, boron was released to the leaching water at slower amounts, suggesting the possibility of longer protection of treated wood in service. Dauvergne et al. (2000) reported that the mixture of boric acid, glycerol, and glyxocal impregnated Wood pine results in less boron leaching due to formation of complexes. Lloyd et al. (1990) reported that the addition of polyols to borate solutions greatly increased the boron stability through borate/polyolchelate complexion.

Wood strength is affected when wood is treated with preservatives or fire retardant (FR) chemicals (Winandy and Margeret, 1988). Many of the metallic oxides commonly used in water-borne preservative formulations react with the cell wall components by undergoing hydrolytic reduction upon contact with wood carbohydrates. This process, known as fixation, oxidizes the wood cell wall component and may reduce wood strength (Dauvergne et al., 2000). The relative impact of various water-borne preservative systems is directly related to the preservative chemistry and severity of its fixation/precipitation reaction (Winandy, 1996). Water-borne preservative treatments generally reduce the mechanical properties of wood more than oil-type preservative treatments, because water-borne preservative chemicals physically react with the wood cell wall material (Fruno and Gato, 1978). Toker et al. (2008) studied about the compression strength parallel to grain (CSPG) of Oriental beech and Calabrian pine impregnated with boric acid, borax and sodium perborate. They found that CSPG of both wood specimens impregnated with borates were lower than the untreated wood specimens. Simsek et al. (2010) studied modulus of rupture (MOR) of Oriental beech wood impregnated with ammonium pentaborate octahydrate (APBO), ammonium tetrafluoroborate (ATFB) and sodium tetrafluoroborate (STFB). They found that MOR of borate- treated Oriental beech was lower than untreated wood.

This study was performed to determine some physical properties such as surface roughness and oven 
dry density, and some mechanical properties such as modulus of elasticity of Oriental beech wood impregnated with aqueous solutions $(0.25 \%, 0.50 \%, 1.50 \%$, and $3.00 \%$ ) of ammonium pentaborate octahydrate (APBO), ammonium tetrafluoroborate (ATFB) and sodium tetrafluoroborate (STFB).

\section{MATERIALS AND METHODS 2. MATERIJAL I METODE}

2.1 Preparation of test specimens and chemicals 2.1. Priprema uzoraka drva i kemikalija

Wood specimens measuring 20 (tangential) x 20 (radial) x 360 (longitudinal) mm, 20 (tangential) x 20 (radial) x 20 (longitudinal), and 75 (tangential) x 6 (radial) x 150 (longitudinal) $\mathrm{mm}$ were prepared from airdried sapwood of Oriental beech for MOE, oven dry density and surface roughness tests, respectively. Aqueous solutions of ammonium pentaborate octahydrate (APBO), ammonium tetrafluoroborate (ATFB) and sodium tetrafluoroborate (STFB) were dissolved in distilled water at concentrations of $0.25 \%, 0.50 \%$, $1.50 \%$, and $3.00 \%$. Ammonium pentaborate octahydrate was purchased from Alfa-Aesar Chemicals while ammonium tetrafluoroborate and sodium tetrafluoroborate were purchased from Sigma-Aldrich Chemicals. Purities of APBO, ATFB, and STFB were 99.5\%, $\geq 98 \%$, and $97-100 \%$, respectively.

\subsection{Impregnation method}

\subsection{Metoda impregnacije}

Wood specimens were impregnated with aqueous solutions of borates according to ASTM D 1413-76 (1976). Treatment solutions were prepared the day before the impregnation for homogenizing. A vacuum desiccator used for the impregnation process was connected to a vacuum pump through a vacuum trap. Vacuum was applied for $60 \mathrm{~min}$ at $760 \mathrm{mmHg}$ before supplying the solution into the chamber followed by another $60 \mathrm{~min}$ at $760 \mathrm{mmHg}$ diffusion period under vacuum. Retention of boron was calculated from the following equation:

$$
\text { Retention }\left(\frac{\mathrm{kg}}{\mathrm{m}^{3}}\right)=\frac{G \times C}{V} \times 10
$$

Where:

$G$ - the amount of solution absorbed by the wood $G=T_{2-} T_{1}$

$T_{2}$ - the weight of wood after impregnation (g),

$T_{1}$ - the weight of wood before impregnation $(\mathrm{g})$,

$C$ - the concentration of the solution as a percentage,

$V$ - the volume of the specimen in $\mathrm{cm}^{3}$.

\subsection{Surface roughness $\left(R_{z}\right)$}

\subsection{Hrapavost površine $\left(R_{z}\right)$}

Roughness parameter, which is mean peak-tovalley height $(R z)$, can be calculated from the peak-to valley values of five equal lengths within the profile. Surface roughness measurement was made in the direction parallel to grain according to DIN 4768 (1990).

\subsection{Oven dry density}

2.4. Gustoća drva u suhom stanju

Oven dry density values of wood specimens were determined according to TS EN 2472 standard (1976) and the values were calculated with the following equation:

$$
d_{0}\left(\frac{\mathrm{g}}{\mathrm{cm}^{3}}\right)=\frac{W_{(0)}}{V_{(0)}}
$$

Where

$d_{\text {o }}$ - oven dry density value of wood specimens

$W_{\mathrm{o}}$ - oven dry weight of wood specimens

$V_{0}$ - oven dry volume of wood specimens.

\subsection{Modulus of elasticity (MOE)}

2.5. Modul elastičnosti (MOE)

The modulus of elasticity of wood specimens was determined according to TS EN 310 (1999). Wood specimens had been conditioned at $20{ }^{\circ} \mathrm{C}$ and $60 \% \mathrm{RH}$ for two weeks prior to testing. The $M O E$ of wood specimens treated with borates was calculated using the following formula:

$$
\operatorname{MOE}\left(\frac{\mathrm{N}}{\mathrm{mm}^{2}}\right)=\frac{P \times I^{3}}{4 \times b \times h^{3} \times Y}
$$

Where $P$ is the maximum load $(\mathrm{N}), I$ is span $(\mathrm{mm}), b$ is the width of specimen $(\mathrm{mm}), h$ is thickness of specimen ( $\mathrm{mm})$, and $Y$ is the deflection $(\mathrm{mm})$.

\subsection{Evaluations of test results \\ 2.6. Analiza dobivenih rezultata}

Test results were evaluated by a computerized statistical program composed of analysis of variance and following Duncan tests at the $95 \%$ confidence level. Statistical evaluations were made on homogeneity groups (HG), of which different letters reflected statistical significance.

\section{RESULTS AND DISCUSSION 3. REZULTATI I RASPRAVA}

\subsection{Surface roughness of borate-treated Oriental} beech wood specimens

3.1. Hrapavost površine uzoraka orijentalne bukovine impregniranih boratima

Surface roughness $\left(R_{z}\right)$ values of wood specimens before and after borate treatment are given in Table 1. Our results showed that borate treatments increased surface roughness of Oriental beech. The increase of $R z$ was changed nearly from $30 \%$ to $92 \%$ after borate treatments. Therefore, it was concluded that the surface of borate-treated Oriental beech was rougher after treatment. The wooden materials with rough surface need more sanding process than those with smooth surface. However, sanding process causes a decrease in $t$ of material (Follrich et al. 2006). Our results showed that increased solution concentration of borates did not adversely influence surface roughness of Oriental beech. Among the treatment solutions, 3.00\% APBO caused the lowest increase of surface roughness, while the treatment with $3.00 \%$ ATFB caused the highest increase of 
surface roughness of Oriental beech. Ayrilmis et al. (2006) investigated the effect of various fire retardants on surface roughness of plywood. They found that samples treated with $6 \%$ concentration of boric acid had the highest $R_{z}$ value. Also, they reported that the $R_{z}$ values of borax, boric acid and monoammonium phosphate at higher concentration ( $6 \%$ or $11 \%$ ) were always rougher than at lower concentrations (3\%) except for $11 \%$ concentration of diammonium phosphate. However, the roughness of wood is a complex phenomenon. Several factors, such as anatomical structure of wood, growing characteristics, machining properties and pre-treatments of wood before machining, should be considered for the evaluation of the surface roughness of wood (Aydin and Colakoglu, 2003; Aydın and Colakoglu, 2005; Temiz et al., 2005).

\subsection{Oven dry density values of borate-treated Oriental beech wood specimens}

3.2. Vrijednosti gustoće u suhom stanju uzoraka orijentalne bukovine impregniranih boratima

The oven dry density values of wood specimens are given in Table 2. The oven dry densities of boratetreated Oriental beech wood specimens were ranged from 0.566 to $0.685 \mathrm{~g} / \mathrm{cm}^{3}$. The oven dry density values of borate-treated wood specimens were higher compared to untreated wood specimen. The highest oven dry density value of wood specimens was obtained as $0.685 \mathrm{~g} / \mathrm{cm}^{3}$ for those treated with $3.00 \%$ APBO. The lowest oven dry density value was obtained as $0.547 \mathrm{~g} /$ $\mathrm{cm}^{3}$ for untreated Oriental beech. According to our results, there was a statistical difference in oven dry density values between untreated Oriental beech and impregnated Oriental beech with $3 \%$ concentration of all borates. Toker (2007) found that oven dry density values of boric acid, borax and sodium perborate treated wood specimens were higher than values of untreated wood specimens. Our results are consistent with data from Toker (2007). Density plays an important role in influencing both physical and mechanical properties of wood and wood-based materials (Akbulut et al., 2004). There is, in fact, a close correlation between mechanical properties, hardness, abrasion resistance and heat value of wood on the one hand, and density on the other (Kollman and Cote, 1968). Also, wood density is an important factor determining possible uses of wood. For instance, strength, flexibility and surface hardness of heavy wood are higher than those of light wood. It gives better protection against corrosive effects. In some situations, it is desirable for wood to be soft, easy processing and have lower shrinkage and swelling. This can be possible when wood is light (Ors and Keskin, 2008). According to our results, borate treatment increased oven dry density values of wood specimens.

\subsection{MOE of borate treated Oriental beech wood} specimens

3.3. Modul elastičnosti uzoraka orijentalne bukovine impregniranih boratima

The MOE of wood specimens are given in Table 3. The MOE values of borate-treated wood specimens were lower compared to untreated wood specimen. Our results showed that borate treatments decreased MOE of Oriental beech (1.42 - $15.18 \%)$. The highest MOE value of wood specimen was $11821 \mathrm{~N} / \mathrm{mm}^{2}$ for untreated Oriental beech. The lowest MOE value was $10026 \mathrm{~N} / \mathrm{mm}^{2}$ for treated specimens with $3.00 \%$ APBO. In general, the MOE values of wood specimens were the lowest for those treated with $3.00 \%$, $1.50 \%, 0.50 \%$ and $0.25 \%$, respectively. No statistical difference was found in MOE values between untreated Oriental beech wood and borate-treated Oriental beech wood. Colakoglu et al. (2003) found that MOE levels of laminated veneer lumber treated with $5 \%$ boric acid were reduced by $3.8 \%$ compared to untreated control. Gerhards (1970) found that fire-retardant chemical treatment and kiln-drying reduce the $M O E$ of wood by an average of $5 \%$. Toker et al. (2009) re-

Table 1 Surface roughness $(R)$ values of borate-treated Oriental beech wood specimens

Tablica 1. Vrijednosti hrapavosti površine uzoraka orijentalne bukovine impregniranih boratima

\begin{tabular}{|c|c|c|c|c|c|c|}
\hline \multirow{2}{*}{$\begin{array}{l}\text { Chemicals } \\
\text { Kemikalija }\end{array}$} & \multirow{2}{*}{$\begin{array}{c}\text { Concentration } \\
\text { Koncentracija } \\
\%\end{array}$} & \multicolumn{2}{|c|}{$\begin{array}{c}\text { Before impregnation } \\
\text { Prije impregnacije }\end{array}$} & \multicolumn{2}{|c|}{$\begin{array}{l}\text { After impregnation } \\
\text { Nakon impregnacije }\end{array}$} & \multirow{2}{*}{$\begin{array}{c}\text { Change } \\
\text { Promjena } \\
\%\end{array}$} \\
\hline & & Mean $^{\mathrm{a}}$ & SD & Mean $^{\mathrm{a}}$ & SD & \\
\hline Untreated / neimpregnirano & - & 32.92 & 12.37 & - & - & - \\
\hline \multirow{4}{*}{ APBO } & 0.25 & 34.54 & 7.99 & 51.02 & 14.57 & +47.71 \\
\hline & 0.50 & 28.93 & 2.36 & 46.07 & 5.28 & +59.25 \\
\hline & 1.50 & 28.22 & 6.38 & 50.95 & 6.31 & +80.55 \\
\hline & 3.00 & 37.12 & 11.12 & 48.28 & 6.60 & +30.06 \\
\hline \multirow{4}{*}{ ATFB } & 0.25 & 33.77 & 7.78 & 59.79 & 6.99 & +77.05 \\
\hline & 0.50 & 35.49 & 15.61 & 60.87 & 18.18 & +71.51 \\
\hline & 1.50 & 35.55 & 20.81 & 59.76 & 19.62 & +68.10 \\
\hline & 3.00 & 28.29 & 11.77 & 54.35 & 20.04 & +92.12 \\
\hline \multirow{4}{*}{ STFB } & 0.25 & 29.66 & 3.10 & 46.44 & 4.11 & +56.57 \\
\hline & 0.50 & 26.13 & 8.25 & 48.75 & 8.39 & +86.57 \\
\hline & 1.50 & 33.25 & 14.90 & 54.83 & 15.64 & +64.90 \\
\hline & 3.00 & 27.99 & 8.16 & 53.15 & 7.79 & +89.89 \\
\hline
\end{tabular}

Note: ${ }^{a}$ Results reflect observations of five wood specimens / Rezultati se odnose na pet uzoraka drva.

SD - Standard deviation / standardna devijacija; APBO - Ammonium pentaborate octahydrate / amonij pentaborat oktahidrat; ATFB - Ammonium tetrafluoroborate / amonij tetrafluoroborate; STFB - Sodium tetrafluoroborate / natrij tetrafluoroborat 
.... Simsek, Baysal: Some Physical and Mechanical Properties of Borate-Treated Oriental...

Table 2 Oven dry density values of borate-treated Oriental beech wood specimens

Tablica 2. Vrijednosti gustoće u suhom stanju uzoraka orijentalne bukovine impregniranih boratima

\begin{tabular}{|l|c|c|c|c|c|c|}
\hline $\begin{array}{l}\text { Chemicals } \\
\text { Kemikalija }\end{array}$ & $\begin{array}{c}\text { Concentration } \\
\text { Koncentracija } \\
\%\end{array}$ & $\begin{array}{c}\text { Retention } \\
\text { Retencija } \\
\mathrm{kg} / \mathrm{m}^{3}\end{array}$ & $\begin{array}{c}\text { Mean } \\
\mathrm{g} / \mathrm{cm}^{3}\end{array}$ & SD & HG & $\begin{array}{c}\text { Change } \\
\text { Promjena } \\
\%\end{array}$ \\
\hline Untreated / neimpregnirano & - & - & 0.547 & 0.018 & $\mathrm{~A}$ & - \\
\hline \multirow{5}{*}{ APBO } & 0.25 & 1.37 & 0.568 & 0.054 & $\mathrm{~A}$ & 3.84 \\
\cline { 2 - 7 } & 0.50 & 2.13 & 0.585 & 0.051 & $\mathrm{AB}$ & 6.95 \\
\cline { 2 - 7 } & 1.50 & 7.16 & 0.614 & 0.056 & $\mathrm{ABC}$ & 12.25 \\
\cline { 2 - 7 } & 3.00 & 18.24 & 0.685 & 0.018 & $\mathrm{C}$ & 25.23 \\
\hline \multirow{5}{*}{ ATFB } & 0.25 & 1.66 & 0.572 & 0.055 & $\mathrm{AB}$ & 4.57 \\
\cline { 2 - 7 } & 0.50 & 2.79 & 0.566 & 0.016 & $\mathrm{~A}$ & 3.47 \\
\cline { 2 - 7 } & 1.50 & 9.10 & 0.684 & 0.052 & $\mathrm{C}$ & 25.05 \\
\hline \multirow{5}{*}{ STFB } & 3.00 & 16.21 & 0.670 & 0.025 & $\mathrm{C}$ & 22.49 \\
\cline { 2 - 7 } & 0.25 & 1.68 & 0.588 & 0.019 & $\mathrm{AB}$ & 7.50 \\
\cline { 2 - 7 } & 0.50 & 2.50 & 0.643 & 0.030 & $\mathrm{BC}$ & 17.55 \\
\cline { 2 - 7 } & 1.50 & 8.33 & 0.646 & 0.017 & $\mathrm{BC}$ & 18.10 \\
\hline
\end{tabular}

Note: ${ }^{a}$ Results reflect observations of ten wood specimens / Rezultati se odnose na deset uzoraka drva.

HG - Homogeneity groups obtained by statistical analysis with similar letters reflecting statistical insignificance at the $95 \%$ confidence level. / homogenost grupe dobivena statističkim testom označena je istim slovima i upućuju na statistički nesignifikantne razlike uz pouzdanost $95 \%$; SD - Standard deviation / standardna devijacija; APBO - Ammonium pentaborate octahydrate / amonij pentaborat oktahidrat; ATFB - Ammonium tetrafluoroborate / amonij tetrafluoroborat; STFB - Sodium tetrafluoroborate / natrij tetrafluoroborat

ported that $M O E$ values of borate-treated Oriental beech wood were lower compared to untreated Oriental beech wood. Yildiz et al. (2004) reported that there was an almost $10 \%$ decrease in $M O E$ of yellow pine (Pinus sylvestris L.) wood samples treated with CCA. Our results are consistent with the findings of the aforementioned studies. According to our results, borate treatments decreased $M O E$ of Oriental beech by $1.42 \%$ to $15.18 \%$. It may be due to the fact that waterborne preservative formulations do react with the cell wall components by undergoing hydrolytic reduction upon contact with wood sugars. This process, known as fixation, oxidizes the wood cell wall compo- nents and may reduce wood strength (Winandy and Margeret, 1988). Our results showed that, generally, higher concentration levels of borates resulted in lower $M O E$ values of Oriental beech wood specimens. The National Forest Products Association (NFPA) (1973) recommends that the allowable stresses for fire-retardant treated wood for design purposes be reduced by $10 \%$ as compared to untreated wood; the allowable loads for fasteners are also reduced by $10 \%$. Also, it requires a 10 to $20 \%$ reduction in allowable design stress, depending on mechanical property under consideration (NFPA, 1986). Therefore, our results meet NFPA requirements.

Table 3 Modulus of elasticity (MOE) values of borate-treated Oriental beech wood specimens

Tablica 3. Vrijednosti modula elastičnosti uzoraka orijentalne bukovine tretiranih boratima

\begin{tabular}{|l|c|c|c|c|c|c|}
\hline \multirow{2}{*}{$\begin{array}{l}\text { Chemicals } \\
\text { Kemikalija }\end{array}$} & $\begin{array}{c}\text { Concentration } \\
\text { Koncentracija } \\
\%\end{array}$ & $\begin{array}{c}\text { Retention } \\
\text { Retencija } \\
\mathrm{kg} / \mathrm{m}^{3}\end{array}$ & $\begin{array}{c}\text { Mean } \\
\mathrm{g} / \mathrm{cm}^{2}\end{array}$ & SD & HG & $\begin{array}{c}\text { Change } \\
\text { Promjena } \\
\%\end{array}$ \\
\hline Untreated / neimpregnirano & - & - & 11821 & 1274 & $\mathrm{~A}$ & - \\
\hline \multirow{4}{*}{ APBO } & 0.25 & 0.76 & 10990 & 1147 & $\mathrm{~A}$ & -7.03 \\
\cline { 2 - 7 } & 0.50 & 1.23 & 10656 & 1086 & $\mathrm{~A}$ & -9.86 \\
\cline { 2 - 7 } & 1.50 & 3.29 & 10389 & 916 & $\mathrm{~A}$ & -12.11 \\
\cline { 2 - 7 } & 3.00 & 9.58 & 10026 & 1029 & $\mathrm{~A}$ & -15.18 \\
\cline { 2 - 7 } & 0.25 & 0.46 & 11653 & 1277 & $\mathrm{~A}$ & -1.42 \\
\cline { 2 - 7 } & 0.50 & 1.54 & 11523 & 1349 & $\mathrm{~A}$ & -2.52 \\
\cline { 2 - 7 } & 1.50 & 4.65 & 11275 & 1125 & $\mathrm{~A}$ & -4.62 \\
\hline \multirow{4}{*}{ STFB } & 3.00 & 8.44 & 10761 & 1048 & $\mathrm{~A}$ & -8.97 \\
\cline { 2 - 7 } & 0.25 & 0.73 & 11145 & 1186 & $\mathrm{~A}$ & -5.72 \\
\cline { 2 - 7 } & 0.50 & 1.72 & 11034 & 1240 & $\mathrm{~A}$ & -6.66 \\
\cline { 2 - 7 } & 1.50 & 5.97 & 11374 & 1127 & $\mathrm{~A}$ & -3.78 \\
\hline
\end{tabular}

Note: ${ }^{a}$ Results reflect observations of ten wood specimens / Rezultati se odnose na deset uzoraka drva.

HG - Homogeneity groups obtained by statistical analysis with similar letters reflecting statistical insignificance at the $95 \%$ confidence level. / homogenost grupe dobivena statističkim testom označena je istim slovima i upućuje na statistički nesignifikantne razlike uz pouzdanost $95 \%$; $\mathrm{SD}$ - Standard deviation / standardna devijacija; APBO - Ammonium pentaborate octahydrate / amonij pentaborat oktahidrat; ATFB - Ammonium tetrafluoroborate / amonij tetrafluoroborat; STFB - Sodium tetrafluoroborate / natrij tetrafluoroborat 


\section{CONCLUSIONS}

\section{ZAKLJUČAK}

Surface roughness, oven dry density, and MOE of borate-treated Oriental beech were investigated in this study. Borate impregnation was concluded to cause increase in oven dry density and surface roughness, and decrease in MOE of Oriental beech.

In conclusion, borate treatments increased oven dry density values of Oriental beech wood specimens. Wood density affects the possible uses of wood. Heavy wood has better protection against corrosive effects because of its strength, flexibility and surface hardness than light wood (Ors and Keskin, 2008). However, it caused rougher wood surface and lower MOE of Oriental beech. In rougher wood surface, losses occurring in the planing machine are increased and low quality surfaces are attained. Modulus of elasticity is a measure of stiffness of a material. Therefore, $M O E$ values are important for designing wood constructions (Yildiz et al., 2004). Our results showed that borate treatments decreased MOE of Oriental beech by $1.42 \%$ to 15.18 $\%$. However, our results met the requirements of the National Forest Products Association (NFPA) for design purposes.

\section{Acknowledgements - Zahvala}

This study was made as part of M.Sc. Thesis by Hakan Simsek in the Graduate School of Natural and Applied Sciences, Mugla University, 2009. Also, this work was supported by the Scientific Research Projects Foundation of Mugla University.

\section{REFERENCES}

\section{LITERATURA}

1. ASTM-D 1413-76, 1976: Standard test method of testing wood preservatives by laboratory soilblock cultures. Annual book of ASTM standards, pp. 452-460.

2. Akbulut, T.; Kartal, S. N.; Green, III F., 2004: Fiberboards treated with N'-N (1,8 Naphthalyl) Hydroxylamine (NHA-Na), borax, and boric acid. Forest Prod J, 54 (10): 59-64.

3. Aydın, I.; Colakoglu, G., 2003: Roughness on wood surfaces and roughness measurement methods. Kafkas Univ, Journal Artvin Forestry Faculty, 4 (12): 92-102.

4. Aydın, I.; Colakoglu, G., 2005: Effects of surface inactivation, high temperature drying and preservative treatment on surface roughness and colour of alder and beech wood. Applied Surface Science, 252 (2): 430-440. http://dx.doi.org/10.1016/j.apsusc.2005.01.022

5. Ayrilmis, N.; Korkut, S.; Tanrıtanır, E.; Winandy, J. E.; Hiziroglu, S., 2006: Effect of various fire retardants on surface roughness of plywood. Build Environ, 41 (7): 887-892.

http://dx.doi.org/10.1016/j.buildenv.2005.04.011

6. Baysal, E.; Ozaki, S. K.; Yalinkilic, M. K., 2004: Dimensional stabilization of wood treated with furfuryl alcohol catalysed by borates. Wood Science and Technology, 38: 405-415. http://dx.doi.org/10.1007/s00226-004-0248-2

7. Baysal, E.; Yalinkilic, M. K., 2005: A comparative study on stability and decay resistance of some environmen- tally friendly fire-retardant boron compounds. Wood Science and Technology, 39: 169-186. http://dx.doi.org/10.1007/s00226-004-0264-2

8. Brelid, P. L.; Simonson, R.; Bergman, O.; Nilsson, T., 2000: Resistance of acetylated wood to biological degradation. Holz Roh Werkst, 58 (5): 331-337. http://dx.doi.org/10.1007/s001070050439

9. Chao, W. Y.; Lee, A. W., 2003: Properties of Southern pine wood impregnated with styrene. Holzforschung, 57 (3): 333-336. http://dx.doi.org/10.1515/HF.2003.049

10. Chen, P. Y. S.; Puttman, M. E.; Williams, L. H.; Stokke, D. D., 1997: Treatment of hardwood lumber with borate preservation. Forest Prod J, 47 (6): 63-68.

11. Colakoglu, G.; Colak, S.; Aydin, I.; Yildiz, U. C.; Yildiz, S., 2003: Effects of boric acid treatment on mechanical properties of laminated beech veneer lumber. Silva Fenn, 37 (4): 505-510. http://dx.doi.org/10.14214/sf.488

12. Dauvergne, E. T.; Soulounganga, P.; Gerardin, P.; Loubinoux, B., 2000: Glycerol/ glyoxal, a new boron fixation system for wood preservation and dimensional stabilization. Holzforschung, 54 (2): 123-126. http://dx.doi.org/10.1515/HF.2000.021

13. DIN 4768, 1990: Determination of values of surface roughness parameters $R_{\mathrm{a}}, R_{\mathrm{z}}, R_{\max }$ using electrical contact (stylus) instruments. Concepts and measuring conditions, Deutsches Institut für Norming, Berlin, Germany.

14. Drysdale, J. A., 1994: Boron treatments for the preservation of wood-a review of efficacy do to for fungi and termites. The Int. Res. Group on Wood Preservation, IRG/ WP.

15. Follrich, J.; Muller, U.; Gindl, W., 2006: Effects of thermal modification on the adhesion between spruce wood (Picea abies Karst.) and a thermoplastic polymer. Holz als Roh- und Werkstoff, 64: 373-376. http://dx.doi.org/10.1007/s00107-006-0107-y

16. Fruno, T.; Gato, T., 1978: Structure of interface between wood and synthetic polymer (XI). The role of polymer in the cell wall on the dimensional stability of wood polymer composite. Mokuzai Gakkaishi, 24 (5): 287-293.

17. Gerhards, C. C., 1970: Effect of fire-retardant treatment on bending strength of wood. Res. Pap. FPL, US Department of Agriculture, Forest Serv., Forest Prod. Lab., Madison, WI, pp.145.

18. Grace, J. K.; Yamamoto, R. T.; Tamashiro, M., 1992: Resistance of borate-treated Douglas-fir to the Formusan subterranean termite. Forest Prod J, 42 (2): 61-65.

19. Hafizoglu, H.; Yalinkilic, M. K.; Yildiz, U. C.; Baysal, E.; Demirci, Z.; Peker, H., 1994: Utilizations of Turkey's boron reserves in wood preservation industry. Project of the Scientific and Technical Research Council of Turkey (Tübitak) (In Turkish).

20. Jin, S.; Yan, L.; Jing-Yu, W.; Fei, W.; Zhen-Zhong, G., 2014: Fire resistance of boron- containing fire-retardant by TG analysis. Journal of Chemical and Pharmaceutical Research, 6 (1): 332-337.

21. Kartal, S. N.; Hwang, W. J.; Shinoda, K.; Imamura, Y., 2004: Laboratory evaluation of boron- containing quaternary ammonia compound, didecyl dimethyl ammonium tetrafluoroborate (DFB) for control of decay and termite attack and fungal staining of wood. Holz als Roh- und Werkstoff, 64: 62-67. http://dx.doi.org/10.1007/s00107-005-0050-3

22. Kollmann, F.; Cote, W. A., 1968: Principles of wood science and technology I. Solid wood. Springer-Verlag, pp. 149-151. http://dx.doi.org/10.1007/978-3-642-87928-9

23. Lee, H.; Chen, G. C.; Rowell, R. M., 2004: Thermal properties of wood reacted with a phosphorus pentoxide- 
amine system. J. Appl. Polym. Sci., 91 (4): 2465-2481. http://dx.doi.org/10.1002/app.13408

24. Lloyd, J. D.; Dickinson, D. J.; Murphy, R. J., 1990: The probable mechanisms of action of boric acid and borates as wood preservatives. International Research Group on Wood Preservation. IRG/WP/1450. IRG Secretariat, Stockholm, Sweden.

25. Lloyd, J. D., 1993: The mechanisms of boron-containing wood preservatives. Ph.D Thesis, Imperial College of Science, Technology of Medicine, Department of Biology, pp. 352

26. Lloyd, J. D.; Manning, M. J., 1995: Developments in borate preserving technology. B.W.P.D.A. Annual Convention, Borax Inc., U.K.

27. Lyons, J. W., 1970: The chemistry and uses of fire retardants. Wiley Intersciences, New York, pp. 165-168.

28. Murphy, R. J., 1990: Historical perspective in Europe. In: Hemel, M. (ed). Proceedings of the First International Conference on Wood Protection with Diffusible Preservatives, 28-30 Nov., Nashville, Tennessee, pp. 9-13.

29. NFPA, 1973: National design specification for stressgrade lumber and its fastenings. Washington (DC): National Forest Products Association.

30. NFPA, 1986: National design specification for wood construction. Washington (DC). National Forest Products Association.

31. Ors, Y.; Keskin, H., 2008: Ağaç Malzeme Bilgisi. Gazi Kitabevi, 8th Press, Ankara, pp. 199 (In Turkish).

32. Simsek, H.; Baysal, E.; Peker, H., 2010: Some mechanical properties and decay resistance of wood impregnated with environmentally-friendly borates. Construction and Building Materials, 24: 2279-2284.

http://dx.doi.org/10.1016/j.conbuildmat.2010.04.028

33. Su, Wen-Yu., 1997: Development of fire-retardant wood composites using boron compounds and their evaluation methods. Ph.D. Thesis, Kyoto University, Kyoto, Japan.

34. Tamashiro, M.; Yamamoto, R. T.; Grace, J. K., 1991: Treatment of Douglas-fir heartwood with disodium octaborate terahydrate (Tim-Bor) to prevent attack by the Formusan subterranean termite. The International Research Group on Wood Preservation, 22 nd., Annual Meeting Kyoto, Japan.

35. Temiz, A.; Yildiz, U. C.; Aydin, I.; Eikenes, M.; Alfredsen, G.; Colakoglu, G., 2005: Surface roughness and colour characteristics of wood treated with preservatives after accelerated weathering test. Appl Surf Sci, 250 (14): $35-42$. http://dx.doi.org/10.1016/j.apsusc.2004.12.019.

36. Toker, H., 2007: Determination of effects of boron compounds on some physical mechanical and biological properties of wood. Ph.D. Thesis, Gazi University Science Enstitute, Ankara, Turkey, pp. 213 (In Turkish).

37. Toker, H.; Baysal, E.; Ozcifci, A.; Altinok, M.; Sonmez, A., 2008: An investigation on compression strength parallel to grain values of wood impregnated with some boron compounds. Wood Research, 53 (4): 59-68.
38. Toker, H.; Baysal, E.; Simsek, H.; Senel, A.; Sonmez, A.; Altinok, M., 2009: Effects of some environmentallyfriendly fire-retardant boron compounds on modulus of rupture and modulus of elasticity of wood. Wood Research, 54 (1): 77-88.

39. TS EN 2472, 1976: Wood-determination of density for physical and mechanical tests. Turkish Standards Institute, Ankara, Turkey (In Turkish).

40. TS EN 310, 1999: Wood based panels-The determination of static bending strength and modulus of elasticity. Turkish Standards Institute, Ankara, Turkey (In Turkish).

41. Winandy, J. E.; Margaret, E. H., 1988: Wood protection techniques and the use of treated wood in construction: Proceedings. Memphis, TN. Madison, WI: Forest Prod. Res. Soc., pp. 54-62.

42. Winandy, J. E., 1996: Effects of treatment, incising, and drying on mechanical properties of timber: National conference on wood transportation structures. Gen. Tech. Rep. FPL-GTR-94. Madison, WI: U.S. Department of Agriculture, Forest Service, Forest Product Laboratory.

43. Yalinkilic, M. K.; Baysal, E.; Demirci, Z., 1995: Effect of boron preservatives on hygroscopicity of Brutia pine wood. Eng. Sci. J Pamukkale Univ, 1 (2-3): 161-168, (In Turkish).

44. Yalinkilic, M. K.; Takahashi, M.; Imamura, Y.; Gezer, E. D.; Demirci, Z.; Ilhan, R., 1999: Boron addition to non or low formaldehyde cross-linking reagents to enhance biological resistance and dimensional stability for wood. Holz Roh Werkst, 57 (1): 151-163. http://dx.doi.org/10.1007/s001070050358

45. Yalinkilic, M. K., 2000: Improvement of boron immobility in the borate treated wood and composite materials. Ph.D.Thesis, Kyoto University, Kyoto, Japan.

46. Yuksel, M.; Baysal, E.; Toker, H.; Simsek, H., 2014: Combustion characteristics of Oriental beech wood impregnated with commonly used borates. Wood Research, 59 (1): 39-50.

47. Yildiz, U. C.; Temiz, A.; Gezer, E. D.; Yildiz, S., 2004: Effects of wood preservatives on mechanical properties of yellow pine (Pinus sylvestris L.) wood. Build Environ, 39 (9): 1071-1075. http://dx.doi.org/10.1016/j.buildenv.2004.01.032

\section{Corresponding address:}

\section{Dr. ERGUN BAYSAL}

Mugla Sitki Kocman University

Faculty of Technology

Department of Wood Science and Technology

Kotekli, 48000, Mugla, TURKEY

e-mail: ergun69@yahoo.com 